\title{
RECENT LEGISLATIVE INDULGENCES TO DELINQUENT TAXPAYERS
}

\author{
WAdE S. SMITH*
}

Tax authorities have been nearly unanimous in asserting that prompt and vigorous enforcement is the very heart of tax collection. Heretofore, legislators have recognized that taxes are paid only under compulsion, and have buttressed the tax laws of their states with provisions calculated to make prompt payment the easiest, and safest, course for the taxpayer. But the spectacle accompanying the past few years' high property tax delinquency ${ }^{1}$ has been that of a wild legislative scramble to remove compulsion in fact, if not in the letter of the law. There has been a mass of indulgences undermining the morale of the taxpayer who pays promptly while extending to delinquents, without distinction as to their, real needs, every opportunity to continue delinquent under the pleasantest circumstances which can be devised.

Only three states, Rhode Island, Vermont, and Delaware, have failed to join in the procession. In the other 45 states tax moratoria, in mild or drastic form, have been enacted. As might be expected, NJew England has seen the fewest legislative concessions to tax delinquents, probably because here the tradition of strict enforcement has been strongest. Elsewhere throughout the nation states have responded to high current and accumulated delinquencies with laws marked by the utmost generosity.

The indulgences granted have ranged from minor extensions of the date delinquency begins, through easy payment plans, to actual compromise of the amount due. By far the most important have been those laws permitting the delinquent to amortize his arrearages over a period of one or more years, sale of the tax lien being stayed in the meantime, and those laws making adjustments in the period and terms of redemption after sale of the lien but before title is issued. But blanket moratoria on tax sales and foreclosures, indiscriminate penalty reductions, and miscellaneous

-A.B., I933, Oberlin College. Staff member of the National Municipal League. Contributing editor of the National Municipal Review. Author of numerous pamphlets on tax collection procedures.

${ }^{1}$ Current tax delinquency probably reached its peak during 1932-33, when about one fifth of the levies due and collectible were unpaid. In some sections accumulated delinquencies on many properties exceeded assessed valuations. For a thorough discussion of the extent and distribution of tax delinquency, zec Current Tax Dexinquenct (Dept. of Commerce, Bureau of the Census, Division of Real Eroperty Taxation, Washington, r934) Pts. I and II. 
concessions bearing little or no relation to the condition of the individual taxpayer, have been enacted in plenty. ${ }^{2}$

It is of course necessary to recognize that this has been emergency legislation. However unwise much of it may be, it was passed by legislatures which believed it necessary to avert economic (or political) catastrophe. Further, in the face of the necessity for making concessions, there was little precedent to guide legislators as to their form. Theoretical objections to certain moratoria had little weight in states in which lax enforcement procedures have been the rule rather than the exception, and where the tax collection laws have never provided anything approaching a real system of tax collection. Where taxes have been collected in normal times more by the sufferance of the taxpayer than by the authority of government, it is not surprising that in time of emergency the palliative has been sugar-coated.

The state ${ }^{3}$ tax collection moratoria fall more or less regularly into groups: laws extending the original due date, laws extending the date the penalty attaches, laws reducing the amount of the penalty or interest or both, laws postponing tax sales, laws authorizing instalment payment of back taxes, laws adjusting the date and terms of redemption after sale but prior to foreclosure, laws altering the terms of foreclosure, and laws compromising the amount due.

Thirteen states have either arbitrarily extended the due date or authorized local collection authorities to do so. . They are Massachusetts, New York, Illinois, Wisconsin, Iowa, Nebraska, West Virginia, North Carolina, Florida, Mississippi, Arkansas, Louisiana, and California. Several other states have adjusted the due date to fit new instalment methods of paying current taxes, but such changes can hardly be considered as moratoria. The majority of the extensions were for relatively short periods, as from the first to the fifteenth of a month, or for three or six month periods. Some states renewed the extensions.

Adjustments in the date or amount of penalty for late payment have been made by all except New Hampshire, Rhode Island, Vermont, Delaware, and Alabama. Many of the changes have been minor, either slight extensions of the date, or fractional reductions in the penalty or interest rate. And many of the concessions have

\footnotetext{
'Tax authorities are pretty well agreed that, ideally, the tax should be payable in the first instance like any other bill-in ten to thirty days. The penalty should begin at once and exceed the normal rate of interest. Sale of the lien should occur within 2 year of the date tax was due (to insure the levying unit use of the-funds for the year in which levied), and not more than two years should elapse after sale until absolute title is vested in the purchaser. Enforeement should be prompt and inflexible. See Report of the Committee on a Model Tax Collection Law of the National Municipal League (1935) 24 NAT. MuN. REv. No. 5 (Supp.).

"Only state legislation is considered here. However, many indulgences have been granted by city ordinance or city charger amendment, among the latter being Detroit's famous seven year payment plan which, together with a refunding plan, virtually rehabilitated that city's finances. The municipal action has been generally more restrained than that of the state legislatures, and tended to distinguish between taxpayers on the basis of causes of delinquency, probably because most of the municipal plans have been devised by city treasurers and tax collectors in close touch with the exact local situation and therefore have a closer relation to the facts of delinquency in each instance.
} 
been more apparent than real, inasmuch as remissions of penalties have frequently been conditioned on prompt payment of current taxes.

Thus, Pennsylvania abated interest and penalty on 1933 and prior taxes due first. class cities if the delinquent arrearage was paid in four equal annual instalments and current taxes were paid when due. ${ }^{4}$ A similar concession was granted to delinquents of all other units for 1934 and prior if 20 per cent of the arrearage was paid by November 1, 1935, and 20 per cent each November Ist until 1939..$^{5}$ In both instances default on the payments restored the lien to its former status, and taxes for which liens had been sold to private individuals were not eligible.

Indiana provided that taxes of I93I and later, delinquent on January I, I935, might be paid up to November I, 1935, without penalty or interest other than that accrued on January $x$, 1935. After that date the previous penalty was displaced by a total penalty of ro per cent added to the tax. ${ }^{6}$ The penalty on special assessments paid within a year was also waived. ${ }^{7}$

Wisconsin granted considerable local option in regard to both amount of penalty and the date at which it should attach, by providing ${ }^{8}$ that by two-thirds vote the local governing body of a town, village, or second, third, or fourth class city might extend the date without penalty; first class cities were given a comparable option. ${ }^{9}$ Another law ${ }^{10}$ authorized the governing bodies to postpone I934 taxes due March 22, 1935, to July 1st, 1935, and 1935 taxes to the corresponding date, if the taxpayer filed an application for such extension. This law was later amended ${ }^{11}$ to give the extension whether application were filed or not. Nebraska attempted a drastic long-term postponement in penalty dates ${ }^{12}$ only to have the law declared unconstitutional.

Kansas $^{13}$ authorized county treasurers to refund all penalties, interest, costs; and expenses paid by persons who between January I, 1935, and February 25, I935, redeemed land previously sold for taxes to the county. Virginia authorized her local governing bodies to release taxes for 1935 and prior years from penalty, interest and costs, under prescribed conditions ${ }^{14}$ and provided also ${ }^{15}$ that the release should be conditional upon payment within six months of the effective date of the act (January I6, 1936).

Texas released all penalties and interest on taxes delinquent on August I, 1934, if paid on or before March 15, 1935, and in the same act declared it to be the policy of the legislature to grant no further penalty, interest, or cost concessions after June

\footnotetext{
' $\mathrm{Pa}$. Laws 1935, Act 75, as am'd by Act 180 . Examples given are from legislation enacted during 1935 and 1936, as being typical of those adopted earlier and having the added virtue of being more recent. Local or special laws, in which several states, notably South Carolina, indulged, are not discussed, since they follow the general pattern. Neither is any attempt made to unscramble the ramifications of Illinois law relating to Cook County (Chicago).

${ }^{5}$ Id., Act 52, as am'd by Act I8o.

-Ind. Laws 1935, c. 166 .

Wis. Laws 1935, c. 2.

${ }^{10}$ Id., c. 7 .

${ }^{12} \mathrm{Neb}$. Laws 1935 , c. 156.

u V. Laws I935, c. 55 .

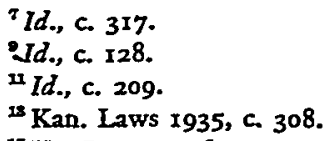


$30,1935 .^{16}$ Idaho cancelled penalties and interest in excess of the 2 per cent flat penalty added at time of delinquency, on all irrigation district assessments for 1928r933 inclusive. ${ }^{17}$ Washington remitted penalties and interest on 1932 and prior delinquencies if at least one half of the taxes due for any one of the years was paid before March 30, I935, provided no judgment had been entered or certificate issued to other than the county. ${ }^{18}$

Twenty-three states altered the date of the tax sale to give additional time to the tax delinquent. They-were New Hampshire, New York, Pennsylvania, Ohio, Indiana, Michigan, Wisconsin, Minnesota, Iowa, Virginia, West Virginia, North Carolina, Georgia, Florida, Mississippi, Louisiana, Montana, Wyoming, Colorado, New Mexico, Arizona, Utah, and Nevada. Extensions ranged from a few months up, there being several stays of sales for a period of several years or more.

Typical of the shorter extensions was that of New Hampshire ${ }^{19}$ which extended the lien from July I to October I during I935 and I936, this being, incidentally, the only moratorium passed by this state. New York stayed sale of property on which back taxes were being paid in instalments, ${ }^{20}$ and Pennsylvania placed authority for delaying tax sales in the courts. Up to March 31 , 1937, the court of common pleas may stay a sale, ${ }^{21}$ and the county courts on petition of the county commissioners may adjourn a sale from time to time, but not later than May $\mathrm{I}, 1937 .^{22}$. Indiana stayed sales during 1935 on lands delinquent December, 1934. If taxes of I934 payable in r935 were paid when due, no such lands were to be offered for sale during 1935, either. Special assessments were not included in the stay. ${ }^{23}$

Twenty-five states authorized instalment payment of back taxes, under amortization plans spreading payments over from one to ten years. They were Massachusetts, New Jersey, Pennsylvania, Ohio, Indiana, Illinois, Michigan, Wisconsin, Minnesota, South Dakota, Macyland, Virginia, South Carolina, Florida, Alabama, Arkansas, Louisiana, Oklahoma, Montana, Idaho, Arizona, Utah, Washington, and Oregon. Specific provision was usually made that default in any payment restored the lien to its former status, and interest and penalty concessions were made in most instances. Many of the laws set forth payment conditions in detail, but a few merely conferred authority upon local units to accept instalment payments.

New Jersey permitted taxes and assessments, plus penalty and interest charges, to be spread over five years in monthly or quarterly instalments bearing 7 per cent interest, provided 1935 taxes were paid when due. ${ }^{\mathbf{2 4}}$ Indiana permitted payment of delinquent taxes in 16 equal semi-annual instalments bearing 4 per cent interest, the first instalment due in May, 1936, and current taxes to be paid at the same time. ${ }^{25}$ Michigan permitted $193^{\mathrm{I}}$ and prior taxes to be paid in ten equal annual instal-

\footnotetext{
${ }^{18}$ Tex. Laws 1935, H. C. R. 13.

${ }^{18}$ Wash. Laws 1935, c. I66.

20 N. Y. Laws I935, c. 725 .

Id., Act I, as am'd by Act 390.

${ }^{4}$ N. J. Laws I935, c. 42.
}

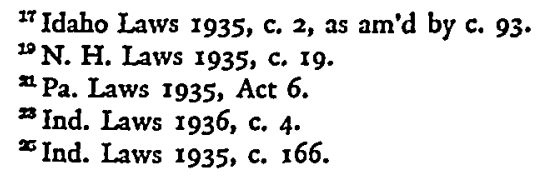


ments, ${ }^{26}$ the 1935 legislature extending the period to include 1932 taxes. Maryland authorized local units to accept instalment payment of arrears over a five year period, and by resolution abate penalties and interest accruing during the period. ${ }^{27}$ One of the more complicated systems, adopted in Illinois, ${ }^{28}$ was declared unconstitutional by the courts. This provided for the spread of delinquent taxes for 1932 and prior years in seven annual instalments beginning August I, 1935, penalty and interest to be remitted but interest at 6 per cent to be paid. On April 17, 1936, the Illinois Supreme Court affirmed a decision of the lower courts holding this law inconsistent with Section 22, Article 4, of the state constitution, prohibiting special legislation. ${ }^{28}$

Alterations in redemption periods and terms were made by thirty-four states, or by all except New Hampshire, Vermont, Rhode Island, Connecticut, New Jersey, Ohio, Indiana, Missouri, Nebraska, Delaware, Maryland, Virginia, Oklahoma, and Colorado. They ranged from a reduction in the penalties or other charges to be paid by the owner to redeem his property from the purchaser of the tax lien, to extensions of the time within which such payment could be made.

Massachusetts ${ }^{30}$ permitted a taxpayer to secure an extension of the lien for one year by paying not less than 25 per cent of the original amount due, but prohibited any extension beyond the one year. Interest in an order for the abatement of a lien was reduced from 6 to 5 per cent. ${ }^{31}$ Pennsylvania ${ }^{32}$ provided that if the lien were purchased by the county, it could be redeemed at any time if all 'taxes, interest, and costs were paid. Penalties were waived. The regular penalty for redemption was reduced from 25 to 15 per cent. $^{33}$ Pennsylvania ${ }^{34}$ and Massachusetts ${ }^{35}$ both permitted partial redemption.

Illinois permitted a home owner to offer payment for all arrears, whereupon the court might waive any and all accrued interest and penalties added after foreclosure. $^{36}$ Another Illinois statute ${ }^{37}$ providing that lands forfeited to the state for 1929-33 delinquencies might be released by paying taxes due plus costs with 5 per cent interest in lieu of other penalty and interest, was ruled unconstitutional by the state attorney general. ${ }^{38}$ Minnesota ${ }^{39}$ provided that any taxpayer with delinquencies for 1933 and prior, to which 1934 taxes had attached on January 1,1936 , might appear before the clerk of the district court and confess to a judgment for the total due, and thereafter pay the total, plus costs, waiving interest and penalty, in ten equal annual instalments, the privilege to be available before the court until November I, 1937 . West Virginia extended to December 3I, 1935, the time for redeeming forfeited lands without payment of interest or costs, if payment were made by that date of

\footnotetext{
${ }^{20}$ Mich. Laws 1933, Act 126.

${ }^{27}$ Md. Laws 1935, c. 387 .

28 Ill. Laws I935, H. B. 783.

20ople ex rel. Clarke v. Jarecki, I N. E. (2d) 855 (Ill. i936).

${ }^{20}$ Mass. Laws I935, c. 4 I4.

Pa. Laws I935, Act 356 .

Id., Act 138 .

*1ll. Laws 1935, H. B. 204.

${ }^{*}$ Opinion to the Governor, June 18, 1935.

Id., c. $2 \mathrm{r} 8$.

Id., Act $24 \mathrm{I}$.

${ }^{20}$ Mass. Laws r935, c. 354 .

${ }^{87} I d$. H. B. 568 .

Minn. Laws 1935-36, c. 72.
} 
taxes levied and all taxes which would have been levied had there been no foreclosure. ${ }^{40}$ Partial redemption by the holder was also permitted ${ }^{41}$

Twelve states granted concessions in regard to the date of foreclosure and issuance of the deed to the property. They were Massachusetts, New York, Wisconsin, North Dakota, Kansas, North Carolina, Florida, Tennessee, New Mexico, Arizona, Utah, and Washington. Most changes were minor. North Dakota suspended the issuance of tax deeds until December $3^{1}$, $1937 .^{42}$ North Carolina authorized a general extension of foreclosures. ${ }^{43}$ The other stays were of the same pattern.

Ten states passed measures compromising the total amount due. All of them are worth noting briefly.

Connecticut ${ }^{44}$ provided that on application and plea of inability to pay, and with the approval of the state tax commission and the attorney general, the real and personal property taxes of a corporation may be wholly or partially abated by a municipality, if necessary to render the corporation eligible for a federal loan. New Jersey ${ }^{45}$ authorized municipalities, except in first class counties, to abate, review, and adjust past due taxes and assessments of corporations under the jurisdiction of bankruptcy receivers. Consent of the state tax commission is necessary. Idaho ${ }^{46}$ authorized the county commissioners to cancel or adjust irrigation district taxes if necessary to render the property owner eligible for federal aid.

New York $^{47}$ and Florida ${ }^{48}$ established special boards to compromise past-due taxes. New York authorized creation of county, town, or village tax arrears boards, to examine property under liens acquired prior to January $\mathrm{r}, \mathrm{I} 935$, and, if the total taxes, assessments, and water rates exceeded the assessed valuation, determine the amount to be paid. The Florida law created a Delinquent Tax Adjustment Board in each county to compromise the delinquent state and county real property taxes for 1935 and prior, while a companion law ${ }^{48}$ created similar bodies for cities. Both laws were contested. ${ }^{50}$ Another law ${ }^{61}$ gave adjustment powers to the county commissioners, while another ${ }^{52}$ granted similar powers with respect to delinquent drainage district taxes where the total outstanding arrearage exceeded the total debt requirements of the district. Oregon ${ }^{53}$ authorized the county boards to adjust and settle tax collection claims against lands the chief value of which was green timber damaged by fire.

Outright cancellation of unpaid taxes was offered by four states. Minnesota ${ }^{54}$ cancelled school district taxes prior to 1935 and unpaid for five years or more, when the liens had been acquired by the district. North Dakota ${ }^{65}$ cancelled unpaid per-
${ }^{\infty} \mathrm{W}$. Va. Laws $1935, \mathrm{c} .54$.
«Id., c. gr.
N. D. Laws 1935, c. 277.
a N. C. Laws 1935, c. 313 .
"Conn. Laws 1935, c. 63.
N. J. Laws 1935, c. Ix9.
«Idaho Laws 1935, Ist Spec. Sess., c. 42.
¿ Fla. Laws 1935, c. 17406.
"N. Y. Laws 1935, c. 799.
In Richey v. Wells, $x 66$ So. 8x7 (Fla. x936), the state Supreme Court held the county act unconstitutional. It divided evenly on the validity of the city act in City of Marianna v. Davis (unreported as yet), dismissing a motion for a permanent injunction against the city.
Fla. Laws 1935, c. I6910.
Id., c. 17458.
* Ore. Laws 1935, c. 367.
st Minn. L2ws 1935, c. 60 .
$\approx$ N. D. Laws 1935, c. 272. 
sonal property taxes together with interest, penalty, and costs, conditional on payment before January I, I935, of a sliding per centage of the tax, dependent upon the age of the lien. Texas barred collection of taxes delinquent prior to December 3 , I919, and amended the constitution to give the legislature power to remit taxes delinquent for ten years. ${ }^{58}$ Illinois ${ }^{57}$ provided that no charge for taxes or penalty might be made for years prior to the incumbency of the present owner.

In granting many of these indulgences, the states have been responding to a situation in which it was evident that in many instances arrearages simply would not be paid under existing statutes. Many of the moratoria must undoubtedly be viewed in the light of attempts to salvage what little could be collected and wipe the books clean of the rest, making the process as painless as possible.

On the whole, however, the indulgences have gone beyond this spontaneous position. They show the effects of pressure-group lobbying and public hysteria carrying over into the legislative chambers. Real estate groups and taxpayers' associations, generally lacking in knowledge of tax theory and caring only for their limited interest, have united in vociferously demanding that the legislators "save our homes." The fact that many of the indulgences are more to the advantage of the speculator than to the homeowner and farmer is, of course, due in part to the lack of accurate information on the distribution and incidence of tax delinquency during the earlier years when the trend of this legislation was established, and in part to the difficulty of herding the sheep from the goats in any hastily contrived legislation.

But while lobbyists and public hysteria can be blamed for the form the legislation took in many instances, the economic situation itself made indulgences in some form inevitable in many sections. Tax delinquency was well on its way to serious proportions before the depression. The financial storm merely broke down the system, and practically obliterated in many communities the mainstay of tax collection, the tax title buyer.

Normally, unpaid taxes would have run their course to sale by the levying unit, bringing to that unit, after delay but with compensating penalties and charges, the original revenue necessary for the operation of government. After sale, collection would normally have continued but with the buyer of the tax certificate supplanting the governmental unit as collector, so that, prior to the foreclosure date, all but a small percentage of the property would have been redeemed by full payment of the taxes due. Normally, the buying of tax titles has been a well-defined and profitable business, with the buyer financing the tax delinquent on the one hand and the levying unit on the other. But the collapse of realty values, and the tremendous increase in delinquencies, has literally swamped the tax title market, virtually wiping out the tax title buyer by making his business hazardous and unprofitable. Rather than buying lucrative investments, the title buyer has found himself purchasing the actual property, which he rarely wanted even in normal times.

\footnotetext{
Tex. Laws 1935, c. 128.
}

ot IIl. Laws r935, H. B. 213. 
Lacking buyers at tax sales, governmental units soon discovered that enforcing tax collection by means of tax sales simply meant acquiring liens rather than collecting revenues. After a few experiences in bidding in all the property offered, legislatures were urged to provide a way out. And many of the indulgences are basically the efforts of the new and unwilling tax title "buyer," the government itself, to make the most of an unhappy situation and permit payment of delinquencies under whatever terms.

Of course, not all of these tax collection moratoria are wholly to be condemned. Granted the necessity of making some concessions, many of the laws have been drafted to do the least possible damage to normal tax collection habits. Worst of the lot are those arbitrarily extending due dates, slashing penalties, and staying tax sales, without regard to the plight of the tax delinquent as an individual. This type of moratoria has done the most to encourage the "tax dodger" in his profitable attempt to delay payment indefinitely, confident that if he does so the legislature will respond with further concessions.

The best of the laws are, obviously, those which have attempted to differentiate between the deserving and the non-deserving tax delinquent, and have hedged their concessions with provisions designed to maintain current collections. Practically speaking, the amortization of tax arrears under a so-called easy payment plan, with an interest charge slightly in excess of the normal rate in the state, and conditional on payment of current levies when due, is perhaps the best type of moratorium. Extending the redemption period and easing redemption costs to the home-owner has much to recommend it, but in states where the glutted tax lien market has practically removed the tax title buyer, this concession means little in terms of governmental income. And in some cases machinery for compromising the total arrears, if handled by a discriminating adjustment board, will work little harm upon the taxpaying community as a whole.

Nevertheless, the moratorium trend has pushed already loosely administered collection systems toward a new low of chaos and laxity. In only a few states have tax-

\begin{tabular}{|c|c|c|c|c|}
\hline \multicolumn{5}{|c|}{$\begin{array}{l}\text { Recent LegisLative INDULGENCES To DelineUENT TAXPAYERS, I930-1936 } \\
\text { (Local and Special Legislation \& Municipal Acts omitted) }\end{array}$} \\
\hline \multicolumn{2}{|c|}{ States ex Grographical Drvzaroxa } & Dus Dare & Paxaltr Datz & Ayount or Pexalts' \\
\hline \multirow[t]{4}{*}{ Now Eroland } & Manxz & & & Lawe '33, S.B. 352 \\
\hline & New Haypshize & & & \\
\hline & Massaciusettse & Laws '33, ca. $168,254,325$ & See left & Sec left; Laws '35, c. 158 \\
\hline & Comracticur & - & Laws '33, c 216 & See left; Laws '35, c. 63 \\
\hline \multirow[t]{3}{*}{$\begin{array}{l}\text { Aiddlo } \\
\text { Atinntio }\end{array}$} & New Yonx & Laws '35, c 256; Laws '36, c 122 & Lews '33, c. 91 & $\begin{array}{l}\text { Laws '33, c. 168; Laws '35, c. } 2 \\
\text { Law: '36, c. } 135\end{array}$ \\
\hline & New Jaxeex & Laws'33, c. & 266. amended slllsetion proced & ure senerally \\
\hline & Penksszivaru & & & Lam '35, Act 75, am'd, Act 180 \\
\hline
\end{tabular}

2Penalty indicates penalty, interest, conts, or other fees. 
paying habits been what could reasonably be called good. ${ }^{58}$ Elsewhere archaic methods, confused law, and political administration have rendered property tax collection procedures anything but business-like. Some states will of course emerge from the mess with wholesale revisions resulting in improved tax collection systems, but many, it must be feared, will continue the ragged patchwork without taking steps to restore the taxpayer morale destroyed by the moratoria.

Furthermore, the agitation for tax collection indulgences has been predicated, in many instances, on an assertion of the "rights" of property owners, or home-owners, or farmers. The effect, and often the intention, of many of these laws is to subsidize property ownership. Without examining the wisdom or necessity for doing this, other than to note that without it much property would undoubtedly have passed to new owners either directly or after a period during which it was held by the state, it is evident that the act of subsidizing property ownership on the basis of tax delinquency is fraught with dangers to normal tax collection. In general, tax delinquency is no longer expensive and dangerous business. It has been made at most only slightly more expensive than borrowing from ordinary sources to make tax payments and, under the bulk. of these laws, the tax collector as a lending agent has become a creditor who cannot refuse the loan. In some states during the past few years the prompt taxpayer has been nothing less than a philanthropist. It is not to be wondered, therefore, that hitherto conscientious taxpayers have succumbed to the attractive terms offered their delinquent neighbors and have lapsed their own taxes in order to get on the band wagon. Nor is it to be expected that, after this feverish whirlwind of indulgences, the restoration of normal and healthy taxpaying habits will be other than a long and costly process.

\footnotetext{
- It is not to be inferred, however, that all existing normal tax collection law has failed; there are ample reasons for believing, though, that the terms of the law have a definite relation to the ratio of delinquency to current levy. For 2 discussion of this point, limited to four simple criteria (viz., penalty 2t least equal to normal interest rate, relatively short period between due date and delinquency date, tax sale within a year of delinquency, and comparative absence of moratoria) and actual delinquency records, see (1935) 24 Nat. MuN. REv. I8I et seg.
}

Recent Legislative Indulgences to Delinguent Taxpayers, r930-1936 (Local and Special Legislation \& Municipal Acts omitted)

\begin{tabular}{|c|c|c|c|c|}
\hline Tax SacE & Ayortzation Prake & Redzutrton TENus & Foxzcrosure & Courrautses: \\
\hline & & Lave' '33, S.B. 353 & & \\
\hline \multicolumn{5}{|l|}{ Law: '33, Ch. 133} \\
\hline & Lews '33, c 308; Laws' '34, c 218 & Lewt' '35, ce. 218,354 & Law: '34, c. 169 & \\
\hline & & & & Lem: '35, c. 63 \\
\hline \multirow[t]{2}{*}{ Law: '35, c. 725} & & Lew: '32, c. 335 & & Laws '35, c. 799 \\
\hline & 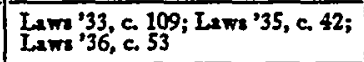 & & & Laws '35, c. 119 \\
\hline $\begin{array}{l}\text { Lews '35, Aet 1, am'd, } \\
\text { Aet } 390\end{array}$ & Laws '33, c 42; Laws '35, Act 180 & Laws '35, Acts $138,241,356$ & & \\
\hline
\end{tabular}

Notz: This eable includes only the most important statutes. Of two or more laws on the ame subject adopted by a legialative seasion, the mont representative and comprehensive is considered here. Laws of 1936 are included only to May in most instances. 
Recent Legislative Indulgences to Delinquent Taxpayers, 1930-1936 (continued)

\begin{tabular}{|c|c|c|c|c|}
\hline \multicolumn{2}{|c|}{ Statzes ar Grographicaz Dtvinons } & \multirow[t]{2}{*}{ Date Dux } & \multirow{2}{*}{ 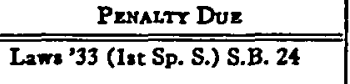 } & \multirow{2}{*}{ 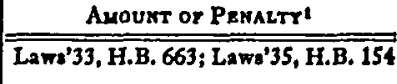 } \\
\hline Eest North & Onio & & & \\
\hline & Irdure & & Laws '32, c. 65 & Laws '32, c. 65; Laws '35, ca. 166, 317 \\
\hline & ILLIX018 & Laws '35, S. B.'s 118, 390 & & Lawe '35, H.B. 209 \\
\hline & Micaigax & & & $\begin{array}{l}\text { Laws '33, Acts 63, 267; Laws '35, } \\
\text { Act 57 }\end{array}$ \\
\hline & Wrsconsm & Laws '33, c. 426 & See left; Laws '35, ca. 2, 209 & See left; Luws '35, c. 128 \\
\hline \multirow{7}{*}{$\begin{array}{l}\text { Wout Naxth } \\
\text { Copatral }\end{array}$} & MINNESOTA & & & Laws '33, cs. 26, 28 \\
\hline & Iown & Laws '35, c 79 & Laws '33, c. 124 & Laws '35, c. 79 \\
\hline & Missours & & $\begin{array}{l}\text { Lama'33, S.B. 94; Lawn'33 (1et } \\
\text { Sp. S.) S.B. } 40\end{array}$ & 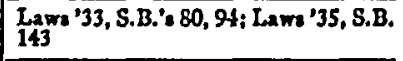 \\
\hline & North Daxota & & & Lam '33, S.B. 1 \\
\hline & Sovtr Daxora & & & Laws '33, H.B. 132 \\
\hline & Nemxasxa & Laws '33, S.B. 7 & L.2m'33, S.B. 7; Lams'35, c. 156" & L.aws '33, S.B. 17 \\
\hline & Kansas & & & Laws '33, H.B. 251; Laws '35, c. 308 \\
\hline \multirow{7}{*}{$\begin{array}{l}\text { Sopth } \\
\text { Aelantlo }\end{array}$} & Marmand & & & Law: '35, c. 387 \\
\hline & Vurcisu & & & Lawe '34, c. 30; Laws '36, ce. 55, 392 \\
\hline & West Vixcimu. & $\begin{array}{l}\text { Lams '33 (Iat Sp. S.) a. 15, 16; } \\
\text { Lawh } 33 \text { (2nd Sp. S.) c. 46 }\end{array}$ & See left & See left \\
\hline & Noxtr Carozima & Lawa '35, c. 126 & Laws '31, c. 83 & See left \\
\hline & Soutra Carolisas & & Laws '33, Acts 140, 662 & See left; Laws '36, Act 256 \\
\hline & Groxgin & & & \\
\hline & FLORIDA & Laws '35, c. 17441 & & See left \\
\hline \multirow{4}{*}{$\begin{array}{l}\text { Eant South } \\
\text { Contral }\end{array}$} & Kentucxx & & Lawr' '32, c. 156 & \\
\hline & TEMNEssE: & & Laws '33, c, 7; Laws '35, c. 50 & Laws '33, c. 7; Laws '35, S.J.R. 20 \\
\hline & AtaBAKa & Laws '33, Acts 80.93 & & \\
\hline & Mississirit & Laws '33, H.B. 888 & Laws '33, H.B. 888, S.B. 203 & Law: '36, H.B. 234 \\
\hline \multirow{4}{*}{$\begin{array}{l}\text { Font South } \\
\text { Contral }\end{array}$} & Axkansas & & & \\
\hline & LourstuxA & Laws '35 (5th.Sp. S.) Act 35 & L2w: '34, H.C.R. 2 & Lawe '34, Act 6 \\
\hline & Oriniroma & & Law: '33, H.B. 151 & Lawo '33, S.B. 2; Lawo '35, c. 33 \\
\hline & Tzxus & & Laws'33,S.B.262;LAm'34,H.B.7 & See left; Lans '35, H.C.R. 13 \\
\hline \multirow[t]{8}{*}{ Mountain } & Montana & & Laws '33, H.B. 1 & Lawe '33, H.B. 38 \\
\hline & IDABO & & & Lawe '33, c. 206; Lawe' '35, co. 2, 93 \\
\hline & Wrourse & & & $L_{2 \mathrm{a}} \cdot 33$, c. 72 \\
\hline & Cororado & & & Lawn '33, H.B. 64; Lawa '35, c. 217 \\
\hline & New Mexico & & & Laws '35, c. 133 \\
\hline & Axizosa & & & Lawe '35, c 30 \\
\hline & $U_{\text {TAx }}$ & & Laws '33, c. 61 & See left \\
\hline & Nerapa & & Laws '33, c. 99 & See left \\
\hline \multirow[t]{3}{*}{ Pacllo } & WasEIKCTOX & & Law: '33, c. 53 & Sec left; Law' 35, c. 166 \\
\hline & Oxzcos & & Lawe '33, c. 326 & See left \\
\hline & Cuzirozru & Lame'33, c. 100 & Lam '33, c. 100 & Lawa' 33, ce. 612, 1018 \\
\hline
\end{tabular}


Recent Legislative Indulgences to Delinguent Taxpayers, r930-r936 (continued)

\begin{tabular}{|c|c|c|c|c|}
\hline TAX SALE & Amortization Plans & REDEMPTION TERMS & Forectosure & Couprourszs \\
\hline Laws ' 33, S.B. 42 & $\begin{array}{l}\text { Laws '33. S.B. 42; Laws '35 (1st } \\
\text { Sp. S.) S.B. } 359\end{array}$ & & & \\
\hline \multirow{2}{*}{$\begin{array}{l}\text { Laws '33, c. 2; Laws'35, } \\
\text { c. } 4\end{array}$} & Laws '33, c. 30; Laws '35, c. 166 & & & \\
\hline & Laws '35, H.B. 783' & $\begin{array}{l}\text { Laws '33, H.B. 669; Laws' '35, H.B. } \\
\text { 204, S.B. 469, H.B. } 568^{*}\end{array}$ & Laws '35, H.B. 213 & \\
\hline Law8 '33, Act 26 & $\begin{array}{l}\text { Laws '33, Act 126; Laws '33 (1st } \\
\text { Sp. S.). Act } 11\end{array}$ & Laws '33, Act 2 & & \\
\hline Laws '33, c. 426 & Laws '34-'35 (Sp. S.) c. 8 & See left; Laws '35, c. 24 & Laws '34-35 (Sp. S.) c. 8 & \\
\hline Laws '33, c8. 98, 337 & Laws '33, c. 121 & $\begin{array}{l}\text { Laws '33, c. 40; Laws '35, c. 387; } \\
\mathrm{L}_{2 w 5} \text { '36, c. } 72\end{array}$ & & Laws' 35, c, 60 \\
\hline \multirow{5}{*}{$\begin{array}{l}\text { Laws '33, c. 133; Laws'33 } \\
\text { (18t Sp. S.) S.F.70, H.F. } \\
232\end{array}$} & & Laws '33, cs. 132, 179 & & \\
\hline & · & $\begin{array}{l}\text { Laws '33, S.B. 1, H.B. 275; Laws } \\
\text { '35, cs. } 275,280\end{array}$ & L2ws '35, c. 277 & Laws '35, c. 272 \\
\hline & Laws '33, S.B. 91; Law8 '35, c. 194 & Laws '33, S.B. 2 & & \\
\hline & & Laws '33, H.B. 427; Lawrs '35, c. 307 & Laws '33, H.B. 427 & \\
\hline & Sec left & & & \\
\hline Laws '36, c. 69 & Laws '34, c. 379 & & & \\
\hline Laws '35, c. 56 & & $\begin{array}{l}\text { Laws '33 (2nd Sp. S.) c. 46; Laws } \\
\text { '35, c. } 91\end{array}$ & & \\
\hline \multirow[t]{3}{*}{ See left; Laws '35, c. 234} & & & $\begin{array}{l}\text { Laws '33, H.B. } 1338 \text {; } \\
\text { Laws '35, cs. } 75,313\end{array}$ & 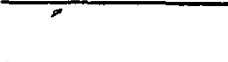 \\
\hline & & See note 2 & & \\
\hline & & $\begin{array}{l}\text { Laws, '34, Act 334; Laws '35, S.B. } \\
173\end{array}$ & & \\
\hline \multirow[t]{4}{*}{ Laws '35, c. 17400} & Laws '33, S.B. 507 & Laws '35, cs. 17404, 17406 & Laks '33, S.B. 192 & $\begin{array}{l}\text { Lams '35, c8. } 16910, \\
17406 *, 17405 *\end{array}$ \\
\hline & & Laws ' 32 , c. 142 & & \\
\hline & & Laws '35, c. 38 & Laws '35, c. 114 & \\
\hline & Laws '35, H.B. 324 & $\begin{array}{l}\text { Laws '33, Act 77; Laws '35, H. B. } \\
324\end{array}$ & & \\
\hline \multirow[t]{2}{*}{ Laws'33,H.B.' в 277,1003 } & & Laws '33, H.B. 432, S.B. 222 & & \\
\hline & Laws '33, Act 16 & Laws '33, S.B. 1; Laws '35, Act 6 & & \\
\hline \multirow[t]{3}{*}{ Laws '34, H.C.R. 2} & Laws '34 (3rd Sp. S.) Act 25 & $\begin{array}{l}\text { Laws '34, Act 158; Laws '34 (2nd } \\
\text { Sp. S.) Act } 30\end{array}$ & & \\
\hline & Laws '33 (18t Sp. S.) S.J.R. 3 & & & \\
\hline & Laws '33 (1st Sp. S.) H.B. 40 & Laws' 33 (1st Sp. S.) H.B. 150 & & Laws ' 35, c. 128 \\
\hline Laws '35, c. 88 & Law6 ' 35 , c. 149 & Laws '33, S.B. 3 & & \\
\hline \multirow[t]{2}{*}{ Lawa '33, cs. 53,73} & & Laws '33, c. 72; Laws '35, c. 127 & & \\
\hline & L2ws '35, c8. 2, 93 & $\begin{array}{l}\text { Laws ' } 33 \text {, H.B. 105; Laws '35, cs. } \\
17,101\end{array}$ & & Laws ' 35, c. 146 \\
\hline \multicolumn{5}{|l|}{ Laws '33, S.B. 486} \\
\hline $\begin{array}{l}\text { Laws'31, c. 104; Laws'33 } \\
\text { (let Sp. S.) c. } 27\end{array}$ & & Laws '31, c. 104; Laws '33, c. 109 & 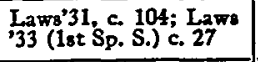 & \\
\hline Laws '33, H.B. 12 & Laws '33, c. 72; Lawrs '35, c. 30 & Laws ' 33, c. 72 & See left & \\
\hline See left & See left & Lawn'33, c. 61; Iaws '35, cs. 85-87 & $\mathrm{L}_{2 \mathrm{we}}{ }^{\prime} 33, \mathrm{c.} 62$ & + \\
\hline \multirow[t]{4}{*}{ See left } & & See left & & \\
\hline & Lams'33, c. 53 & See left & L2w1 ' 35, c. 166 & \\
\hline & Laws ' $33_{k}$ c. 462 & $\begin{array}{l}\text { Laws'35, c. 282; Laws'35 (1et Sp. } \\
\text { S.) S.B. } 48\end{array}$ & & Lams' 35 , c. 367 \\
\hline & & $\mathrm{L}_{2 \mathrm{~ms}}$ '34, c.6; Lams'35, ca. 137,313 & & \\
\hline
\end{tabular}

